\title{
Buchanan at the American Founding: the constitutional political economy of a republic of equals and unequals
}

\author{
John Meadowcroft ${ }^{1}$ (i) \\ Received: 13 March 2020 / Accepted: 20 March 2020 / Published online: 2 April 2020 \\ (c) The Author(s) 2020
}

\begin{abstract}
James M. Buchanan cited the American Founding as an important inspiration for his constitutional vision. Buchanan and the Founders shared a belief in the moral equality of persons and a conviction that social order could be built upon a nexus of contract and exchange. The early revolutionaries were inspired by the classical republican ideal of impartial government serving the public interest, but Buchanan and the later Founders did not believe that relying on political actors to pursue the common good would avert tyranny. Buchanan's insistence on unanimous constitutional agreement highlights the fact that the Constitutional Convention did not obtain the consent of the black Americans who constituted close to one-fifth of the population, but to whom the Founders did not extend the principle of moral equality. Accordingly, Buchanan's work leads to an appreciation of the Founders as an archetype of the constitutional mentality that he advocated throughout his work, but also to an understanding that the Founding fell short of his ideal of genuinely consensual politics. The practical import of Buchanan's work therefore is to facilitate the evaluation of real-world politics - in this case, America's Founding and subsequent political development - and to point the way towards future reforms informed by a constitutional mentality.
\end{abstract}

Keywords Buchanan · American Founding · Constitutionalism · Slavery

JEL Classification B29 $\cdot \mathrm{B} 31 \cdot \mathrm{H} 10 \cdot \mathrm{P} 16$

\section{Introduction}

What are the practical implications of James M. Buchanan's constitutional political economy? Buchanan's work principally was abstract, often formal, and the policy implications of his analysis usually were left implicit. The absence of implications has given Buchanan's work a universal, timeless appeal, but it has also provided scope for others to fill-in the empirical content and practical import of his work. Recently, the implications have been drawn out by scholars hostile to Buchanan's project. Most notoriously, the historian Nancy

John Meadowcroft

john.meadowcroft@kcl.ac.uk

1 Department of Political Economy, King's College London, London, UK 
MacLean (2017) has argued that Buchanan's work was a carefully disguised defense of the rights of the white elite of the Southern United States against the claims of AfricanAmericans excluded from institutions that were legacies of slavery and segregation. Following MacLean, Wendy Brown (2019, p. 62) has argued that Buchanan was an opponent of democracy who "alloyed his brand of free enterprise with the project of white supremacism”. Thomas Biebricher (2018) similarly has identified Buchanan's work with elite attempts to thwart democracy and argued that Buchanan was one of the key intellectual architects of the institutions of contemporary 'neoliberalism'.

Buchanan himself located his work in the tradition of the American Revolution and the Founding of the United States. That positioning took place in numerous passages scattered throughout his oeuvre, rather than in any one systematic treatment. In a reflection on The Calculus of Consent, for example, Buchanan (1986a, p. 19) wrote that he and Gordon Tullock, "more or less explicitly considered our exercise to be an implicit defense of the Madisonian structure embodied in the United States Constitution". In the Preface to The Reason of Rules, Buchanan and Brennan (1985, p. xv) stated their approval of, "the veneration Americans accord their Founding Fathers. James Madison, Benjamin Franklin, Thomas Jefferson", individuals who were, "distinguished by their essential understanding of the reason of rules in political order, an understanding they implanted in the constitutional documents, the 'sacred' texts that have, indeed, worked their influence through two centuries". Buchanan (1992a, p. 62) also welcomed the attribution of the phrase Virginia Political Economy to public choice theory-explaining that his intellectual enterprise was "appropriately described locationally in the commonwealth that produced James Madison and the other Virginia Founders".

However, scholars both sympathetic and hostile to the enterprise of public choice have expressed doubts about Buchanan's attempts to locate his work in that tradition. Dennis Mueller (2013, pp. 67-68), a leading exponent of and authority on public choice, has pointed out that the American constitutional agreement in which "all citizens did not take part, and unanimity was not attained", and in which slavery was perpetuated, would seem to fall significantly short of Buchanan's ideal of the unanimous agreement of the rules to govern post-constitutional politics. From a position of opposition, MacLean (2017, p. 3) has argued that Buchanan's view of the appropriate limits to government power more accurately reflects the intellectual legacy of John Calhoun, the prominent defender of Southern slavery and succession, whose "ideas about government broke sharply from the vision of the nation's founders and the Constitution's drafters".

The present article will argue that Buchanan's constitutional political economy should be understood in the tradition of the American Revolution and the foundation of the Republic. To do otherwise is to misunderstand essential features of Buchanan's enterprise. It will show that Buchanan and the Founders shared moral principles and philosophical foundations. Both understood society to be an emergent order and sought to create an institutional framework that would facilitate the emergence of a free and democratic polity. But applying Buchanan's ideal of unanimous constitutional agreement to the American Founding highlights the fact that the Founders failed to extend the principle of moral equality to the African-Americans who then constituted one-fifth of the population and who were unrepresented at the Constitutional Convention. Accordingly, while the Founders were an archetype of the constitutional mentality that Buchanan advocated throughout his work, the foundation fell short of Buchanan's ideal of genuinely consensual politics. Buchanan's work facilitates the evaluation of real-world politics - in this case, America's Founding and subsequent political development-and points the way towards future institutional reform consistent with a constitutional mentality. 


\section{Buchanan and the American Founders: the constitutional mentality}

Buchanan's constitutional political economy was both normative and positive. The idea of a social contract was a normative device "that facilitates the evaluation of real-world institutions", and "requires us to imagine if people would voluntarily enter into the political arrangements that presently exist" (Meadowcroft 2011, p. 46). Buchanan (1972, p. 78) acknowledged that, "factually and historically, the 'social contract' is mythological... Individuals did not come together in some original position and mutually agree on the rules of social intercourse". But a salient question was whether people could be imagined voluntarily to enter into present arrangements? If not, then the legitimacy of those arrangements was brought into question (Buchanan 1975a, Chapter 10; Buchanan 1977a, p. 103). Constitutional political economy therefore was a method for the normative evaluation of existing social, economic and political arrangements.

Positively, Buchanan understood that constitutions were important protectors of citizens from their governments. Constitutional rules were the principal means of limiting political power and ensuring the rule of law. A constitution was the answer to the classical question: quis custodiet ipsos custodes — who will guard the guardians? (Buchanan 1975a, pp. 17-20; Brennan and Buchanan 1985, Chapter 1).

The American Founding was a deliberate attempt to create a government whose power over its citizens was limited formally. The American revolutionaries sought to create "a new society unlike any that had ever existed anywhere in the world" (Wood 1992, p. 6) that was a democratic republic founded on the consent of the governed in which collective authority was constrained formally by the separation of powers and a system of checks and balances. The revolutionaries believed that the replacement of parasitic monarchical authority with a constitutional democracy would safeguard their liberties and ensure future prosperity (Epstein 2014, pp. 3-5; Wood 1992, pp. 169-73). The American Founding was a model of individuals overthrowing external authority and then introducing constitutional rules as ongoing self-constraints.

Buchanan also understood that a constitution (or absence thereof) was an important determinant of a society's social, economic and political development and, hence, the life chances of individual men and women. At the most basic level, the rules of the game were significant factors in economic development: societies with weak rules of law, ineffective monetary policies, and unqualified executive powers, for example, tended to remain poor, while those with strong rules of law, effective monetary policies and limits to executive power were likely to become wealthy. Moreover, it was not just that institutions mattered in economic development, but that the rules of the game had profound and far-reaching social, political and economic consequences. The rules of the game determined what kinds of wealth was produced, how that wealth was distributed, what social mobility existed, and so on (Brennan and Buchanan 1985, Chapter 1; Buchanan 2003, 2008).

For Buchanan, appreciation of the normative and positive importance of constitutional rules was a "constitutional mentality" (Brennan and Buchanan 1985, p. xviii) —or "constitutional wisdom" (Buchanan 1989a, p. 371) or "constitutional understanding" (Buchanan 1997, p. 231). Buchanan often expressed disappointment that the fundamental salience of the rules of the game was not appreciated more widely. But the American Founders were exemplars of that constitutional mentality; the Founders understood, as few people had done before or since, the long-term significance of constitutional rules (Buchanan 1975a, Chapters 9 and 10, 1989a, 2003; Buchanan and Vanberg 1989; Ostrom 2012). 
Buchanan (1975a, p. 211) believed that appreciation of the power of constitutional rules led to a responsibility for accepting the challenge of rule-making. He categorically rejected the idea that a deep appreciation of the long-run importance of institutions and the emergent nature of social order should lead to faith in evolutionary processes over institutional constructivism: "History need not be a random walk in sociopolitical space, and I have no faith in the efficiency of social evolutionary process". The American Founders had grasped the nettle of institutional construction and by so doing created an historical legacy that changed for the better the lives of many millions of people over more than two centuries (Buchanan 1975a, Chapters 9 and 10, 1989a, 2003; Buchanan and Vanberg 1989).

\section{Ethical individualism: a society of equals and unequals}

Buchanan believed that the intellectual starting point of the constitutional mentality was recognition of the moral equality of all persons. Buchanan (1975a, pp. 3-4) began The Limits of Liberty with a statement of ethical individualism: "the individualist is forced to acknowledge the mutual existence of fellow men, who also have values, and he violates his precepts at the outset when and if he begins to assign men differential weights.... Each man counts for one, and that is that". Similarly, in The Reason of Rules, Brennan and Buchanan (1985, p. 26) explained that their approach to constitutional political economy "requires that all persons be treated as moral equivalents, as individuals equally capable of expressing evaluations among relevant options". Importantly, given the accusations of white supremacism recently levelled against Buchanan, he always was unequivocal that all persons were morally equal and that no second class of persons counted for less than others (Buchanan 1971, 1975a, pp. 3-4, 1989a).

Buchanan's conception of consensual politics followed from the conviction that it always was wrong to impose ends, outcomes, or costs on another person without that person's consent-even if it was thought to be for his or her own benefit. That concept meant that unanimity was an essential component of constitutional agreement because an individual could not enter into a contract involuntarily, "there is no place for majority rule or, indeed, for any rule short of unanimity" (Buchanan 1986b, p. 220; emphasis in original. See also Brennan and Buchanan 1985, Chapter 1; Buchanan 1975a, Chapter 1).

The American Founding was built upon a similar belief in the moral equality of persons. The revolution was a revolt against a monarchical, undemocratic government that ruled on the basis of the inequality of persons - that some people were born to rule and other, lesser people were born to be ruled. As such, colonial governments ruled along lines of patronage and ties of privilege that went back across the Atlantic Ocean to the British monarch. The revolution was a rejection of those ideas and destruction of those relationships. The revolutionaries dismissed the age-old principle of aristocracy by birth and replaced it with the principle of equality - that all men were fundamentally, morally equal. As Jefferson wrote in the Declaration of Independence: "We hold these truths to be self-evident, that all men are created equal". Men were deemed to be equal in their moral worth and equal in their capacity for self-government (Bailyn 1967; Pole 1978; Wood 1992).

It has been argued that those words ring hollow given that the Founders did not consider African-Americans to be equal to white Americans of European descent (Magnis 1999; Mills 1997; Pateman and Mills 2007). It is important to recognize and acknowledge the exclusion of African-Americans from the society of equals envisaged by the Founders, but, 
as Douglass (1852) argued powerfully, the fault was not in the principle of equality the Founders espoused, but in their failure of extend it to all Americans.

The Founders' (partially applied) belief in equality reflected the teachings of the leading Enlightenment scholars that traditional hierarchies were not natural and ordained by God, but were man-made and artificial. Wood (1992, pp. 236-40) has described the widespread belief in Lockean sensationalism during the revolutionary period-the belief that all people were born intellectually, psychologically, and emotionally identical and the differences that emerged came from the influences of their different experiences. Perhaps the most famous example was Adam Smith's (1776, pp. 28-29) claim, published in the same year as the Declaration of Independence, that the differences between a philosopher and a street porter, "arise not so much from nature, as from habit, custom and education", so that no difference existed between the two at birth, little in infancy, but great differences gradually developed over time as they were exposed to different experiences. Not all the American revolutionaries subscribed to such a strong account of the individual as a clean slate, but its extensive currency nevertheless reflected the widely held belief in the enormous scope for human improvement if only society could be organized to the benefit of all, not just a privileged minority (Bailyn 1967; Pole 1978; Wood 1992).

Buchanan (1975a, pp. 15-17), however, counselled that the belief in the moral equality of persons should not disguise the fact that people were unequal in important, non-trivial respects. Indeed, the unique moral value of each individual flowed from their differences. Buchanan (1971, p. 237) wrote that people, "differ in capacities; even at some defined point in time, inequality in endowments (human and nonhuman) is characteristic of the real world". Furthermore, in the real world, people also differed in their possessions of property and wealth and those differences had to be taken seriously in any process of institutional design.

Buchanan (1975a, p. 17) argued that the opening words of the Declaration of Independence had allowed confusion to enter our understanding of the kind of equality imagined by the Founders and that Jefferson should have written, "to their creator, all men are equal", to describe more accurately the Founders' vision of equality. A constitutional agreement must be founded on moral equality, but must also recognize the reality of personal and material inequalities. Buchanan's constitutional political economy required recognition of both natural equality and natural inequality (Levy and Peart 2018).

Buchanan and the Founders derived very different understandings of rights from their similar conceptions of moral equality. The Declaration of Independence was a classic statement of natural rights - the belief that people possess basic human rights qua people, irrespective of whether other people or institutions recognize those rights. That conclusion reflects the views of the key Enlightenment thinkers who inspired the revolutionaries, notably Locke (1689), who articulated influential arguments in favor of natural rights. By contrast, Buchanan (1975a) and Brennan and Buchanan (1985, Chapter 2), rejected natural rights because their existence would imply a source of values external to individual men and women. For Buchanan (1977a, b, p. 244), "the basic Kantian notion that individual human beings are the ultimate ethical units, that persons are to be treated strictly as ends and never as means", meant "that there are no transcendental, suprapersonal norms" such as universal human rights. Accordingly, rights existed only when people agreed to assign rights to one another and mutually to respect those rights. The mutual assignment of rights was the process by which people left the state of nature and entered political society (Buchanan 1975a, Chapter 4; Meadowcroft 2011, pp. 50-51).

While Buchanan (1971, 1975a, Chapter 1, 1979a) rejected the idea that individuals were human putty who could be moulded into perfect beings by a benevolent ruler, he 
nevertheless contended that the desire for self-improvement, even self-transformation, was a defining human characteristic. It was this ability to conceive the possibility that one could live a different life that drove purposeful economic and political behavior. Buchanan's (1979a, p. 259; emphasis in original) project was driven by the idea that, "Man wants liberty to become the man he wants to become". Liberty was the freedom to imagine and ultimately pursue different, possible alternative lives. Political and economic theories assuming that individual preferences were given and fixed and could be captured accurately by external agents were inimical to liberty and the ideals of self-governance and self-transformation (Buchanan 1979a).

Buchanan's constitutional political economy reflected his belief that people sought to create rules to enable the pursuit of their personal, and potentially transformative, conceptions of the good life. Constitutional order freed individuals from ends imposed by others. Like the American Founders, Buchanan believed that a constitution could unleash people's dynamic potential to change themselves and their world.

\section{Contract and exchange}

Buchanan's constitutional political economy described a normative ideal of a society organized according to the principles of contract and exchange. Just as a market economy emerged spontaneously from a series of voluntary, bilateral exchanges between individuals, so that it could be said to have the "consent" of all participants in those transactions, legitimate political institutions similarly could similarly emerge from a series of voluntary, bilateral exchanges between individuals who agreed reciprocally to respect one another's rights. For Buchanan, "the whole enterprise of politics can be viewed only as a complex many-person system of exchanges or contracts", in which, "Individuals must be conceived to join together to explore and ultimately to agree on the establishment of collective entities or arrangements that prove mutually beneficial" (Brennan and Buchanan 1985, p. 25; see also Buchanan 1975a, pp. 50-52; Buchanan and Tullock 1962, Chapter 1).

The definitive example of Buchanan's conception of politics as exchange was the unanimous agreement of political rights. Buchanan showed that theoretically we can envisage that a society of materially unequal individuals will agree unanimously and voluntarily to leave the state of nature and respect one another's rights. The weak voluntarily will enter into the social contract to obtain protection from predation by the strong that characterizes the state of nature; the strong will agree to the social contract because the resources they have allocated previously to predation (and protection from the even-stronger) can then be redeployed to productive activities. The potential for mutual gains from mutual disarmament leads to the agreement of the social contract. Importantly, the social contract is not conceived as one multilateral agreement signed by every member of society in a single moment, but as a series of bilateral agreements between individuals that come to encompass all members of society. Buchanan's belief in unanimity did not imply that everyone raised their hand or cast their ballot in one moment of decision, but that people's decisions to respect one another's rights in their interactions constituted an ongoing series of voluntary, welfare-enhancing exchanges that came to establish universally agreed rights. It was in that way that the mythological social contract was conceived to become an empirical reality (Brennan and Buchanan 1985, Chapter 2; Buchanan 1975a, Chapter 4; Marciano 2009; Vanberg 2004). 
Contract and exchange also were central to the American Revolution. The revolutionaries' rejection of monarchical government reflected and was informed by the development of a society founded upon contract and exchange rather than patronage and privilege. Whereas the old colonial society had been dominated by hierarchical relationships based on duty and obligation - between master and servant, landlord and tenant, husband and wife, parent and child - by the late-eighteenth century America increasingly was characterized by relationships mediated by voluntary contracts between people who considered themselves equals. As Wood (1992, p. 162) described: "in the commercialized eighteenth century[,] contracts became much more voluntary, explicit, and consensual, much less declaratory of previously existing rights and duties and much more the consequences of conscious acts of will". The hierarchical relationship between distant monarch and colonial subjects was anachronistic in a world where contracts voluntarily agreed to by equals mediated most relationships.

Furthermore, whereas monarchical economies relied on agricultural production grounded in traditional tenant farming, mercantilist acquisition abroad, or both, eighteenthcentury America was a commercial society in which cottage industries abounded and trade was near-universal. America's colonial masters did not understand that new economy of commercial exchange and, hence, their attempts to regulate, tax and control it were destined to fail and to provoke dissent (Bailyn 1967, Chapter V).

Exchange also was a powerful democratizing force in American society. Whereas in the past, economic advancement had been restricted to property owners and office-holders able to obtain credit or favor from government, by the late-eighteenth century individuals could cumulatively improve their economic positions by producing goods at home for external sale (Wood 1992, Chapter 18).

That said, within such a seemingly more open society, African-Americans still faced significant formal and informal economic and personal restrictions, most obviously from the institution of slavery, and later from Jim Crow laws and segregation. It is important to acknowledge that the new society of exchange and contract did not encompass all Americans (Roback 1986; Rothstein 2017; Wood 1992, p. 236).

Buchanan shared the revolutionaries' vision of a society founded on contract and exchange between free and equal individuals. That vision may be contrasted with the view that social order is imposed from above by political authority that is characteristic of monarchical and socialist conceptions of society. Buchanan's vision, as Marciano (2009) has described, was founded on an understanding of economics as a science of exchange, not a science of choice, and a similar vision of a social order built on contract and exchange inspired the American Founding. As Buchanan (2007, p. 17) reflected towards the end of his career, "the simple exchange of apples and oranges between two traders" is the "institutional model" that serves as "the starting point for all that I have done". A market economy ultimately may be reducible to the exchange of apples and oranges between two individuals; for Buchanan legitimate political institutions similarly could be reducible to the decisions of two individuals to recognize and respect one another's rights.

\section{A republic without virtue}

The risk that without constitutional constraints democracy could descend into tyranny was a consistent theme of Buchanan's work. For Buchanan, the tragedy of the democratic era was that the individual faced tyranny from people like him or herself, not from distant 
rulers whose privileged lives barely could be imagined. The American revolutionaries had overthrown the rule of George III, the French revolutionaries had ousted the ancien régime, and the Bolsheviks had completed the removal of the Russian aristocracy, but for "modern man tangled in the web of bureaucracy, there is only himself, or others of the same breed" (Buchanan 1975a, p. 188). Tyranny in the contemporary era was imposed by people indistinguishable from ourselves and therefore protection required mutual agreement to self-constraints: "When we speak of controlling Leviathan we should be referring to controlling self-government, not some instrument manipulated by the decisions of others than ourselves" (Buchanan 1975a, p. 188).

The American revolutionaries initially had believed that replacing a colonial monarch with a republic led by virtuous individuals willing to set aside their own private interests for the common good would put an end to tyranny. That belief in a clear distinction between private and public interests was an important component of Enlightenment republicanism. Montesquieu (1749, p. 67) wrote that republican government "requires a constant preference of public to private interest"; education was required to teach governors the virtue of "self-renunciation, which is ever arduous and painful". Rousseau (1671, p. 25) argued that a republic enacted laws that reflected the "general will", which he defined as an amalgamation of the private interests in society, in contrast to the preference of one interest over others: "the will of all ... considers private interest and is merely the sum of private wills. But remove from these same wills the pluses and minuses that cancel each other out, and what remains as the sum of differences is the general will". Classical republicanism aimed to replace monarchical government in which the right to pursue one's own interest through the offices of state was accompanied by a limited obligation to engage in costly public service with a government whose personnel set aside those private interests to govern for the public good.

But as the American state legislatures became filled with self-serving local politicians, who went on to represent their states' interests at the Constitutional Convention, the classical republicans among the revolutionaries had few options but to admit the rarity of genuinely disinterested politicians. Future President John Adams wrote that one could find at most "only one actual disinterested character every five hundred years" (Wood 1992, p. 289). Accordingly, the key question facing the Founders ceased to be how to recruit disinterested individuals into public office sufficient to enable government in the public interest, but how to put in place the necessary safeguards, given the fact of government by self-interested individuals. Hence, in arguing for the separation of powers in Federalist 51 Madison (1788a, b, p. 257) wrote famously that

If men were angels, no government would be necessary. If angels were to govern men, neither external nor internal controls on government would be necessary. In framing a government which is to be administered by men over men, the great difficultly lies in this: you must first enable the government to control the governed; and in next place oblige it to control itself.

The Founders had to face the fact that in the absence of a government of disinterested officeholders serving the common good, overthrowing the colonial government of the British monarch would not necessarily put an end to tyranny. On the contrary, democratic government could produce a popular tyranny unfettered by the practices of patronage and norms of duty that may have constrained monarchical authority.

Buchanan's ethical individualism led to the belief that politics could not involve the pursuit of the public interest because the "public interest" did not exist (Buchanan 1975a, Chapter 1, 1989b). For Buchanan, no such thing as "society" had objective reality, other than the sum of 
the individuals who composed it, so no moral values existed external to the values of individuals. It was an error to speak of the "public interest" because only individuals had interests; no transcendental "social" or "public" values or ends could be discovered, but only the values and ends of different individuals. As Brennan and Buchanan (1985, p. 27) put it, "The state does not act as such, and it cannot seek its own ends or objectives. 'Social welfare' cannot be defined independently, since, as such, it cannot exist".

In the absence of a public interest independent of the private interests of individuals, Buchanan argued that no basis for judging any social outcome was preferable to any other, except in so far as an outcome enabled individuals to attain their own ends: "A situation is judged 'good' to the extent that it allows individuals to get what they want to get, whatsoever this might be, limited only by the principle of mutual agreement" (Buchanan 1975a, p. 4).

If the public interest did not exist, then any attempt to discover or pursue the "public interest" must involve the imposition of one person's or one group's interests on others in the name of the "public interest". Consequently, the idea of virtuous politicians setting aside their own interests and pursuing the common good was a mirage that hid the pursuit of the ends or values that those politicians considered important (Buchanan 1975a, Chapter 1, 1989b). Buchanan conceived of politics as a process of exchange not choice because ideally politics was not about choosing between public and private interests, or arbitrating conflicting private interests, but was a process through which individuals sought to reconcile their interests to arrive at a mutually advantageous outcome.

Indeed, Buchanan argued that even the Founders like Madison, whose efforts undoubtedly produced great benefits for others, became well-informed about constitutional matters and undertook political action to attain, "enhanced power to determine the ultimate collective result" (Buchanan and Vanberg 1989, p. 21). Madison invested time and effort in developing a constitutional mentality because it conferred a position of leadership that allowed him decisively to influence the final outcome of the constitutional process, so his personal investment ultimately was directed towards the attainment of an excludable, private benefit (Buchanan and Vanberg 1989).

Buchanan (1979b) described public choice theory as an understanding of "politics without romance" - an analytical approach in which all political actors are assumed to be selfinterested. That view of politics has been criticized for its seemingly pejorative opinions about political actors, whether politicians, civil servants or voters, who critics argue may often be motivated by high ideals, such as the pursuit of justice and the good society (Kelman 1988; Petracca 1991; Udehn 1996). For Buchanan, however, the belief that political actors are selfinterested described the existential reality of a world in which the public interest did not exist. Understanding that avoiding tyranny required self-constraint, not the recruitment of angelic politicians, was an essential part of the constitutional mentality that Madison had understood and enshrined in the US constitution. Buchanan's analysis recognized the importance of institutional robustness - that effective institutions should not rely on benevolent, other-regarding actors to produce good outcomes (see Boettke and Leeson 2004; Levy 2002; Pennington 2011).

\section{Unanimity, slavery and the status quo}

Buchanan never wavered in his commitment to the principle of unanimity as an essential component of constitutional agreement, even though his belief that no such thing as the public interest existed, only diverse, and potentially conflicting, private interests, meant that 
the requirement of unanimity was extraordinarily demanding. Indeed, Buchanan (1968, p. 90) recognized that unanimity empowered the most recalcitrant individuals to block any proposal, "regardless of the net benefits provided to each person", so that, "[p]ractically speaking, the rule of unanimity would result in few, if any, decisions being made". But Buchanan (1968, 1975a) nevertheless believed that the benefits of leaving the state of nature were so significant that individuals could be conceived to agree unanimously a constitutional contract that included consent to non-unanimous decision-making rules for governing post-constitutional politics and facilitating ongoing collective action.

Unanimity would seem especially to be burdensome in the real world where individuals hold property that will have a significant impact on a post-constitutional future. Hardin (1988, p. 529) argued that the American Founding demonstrated the difficulty-if not the impossibility - of attaining unanimity given that the US Constitution was not agreed to unanimously and its later ratification within each state similarly was not unanimous (e.g., Drinker Bowen 1966, Chapters 22-25). For Hardin (1988, p. 529; emphasis in original), the American Founding demonstrated the practical impossibility of applying Buchanan's ideas and that Buchanan's work had remained essentially abstract because no "positive provisions that would get unanimous support in the face of such divergent abstract views" about the appropriate post-constitutional institutional structure were possible.

The difficulty of reaching agreement at the Constitutional Convention principally turned on the question of slavery and the rights of the slave states to continue that abhorrent practice. The Convention arrived at the compromise, giving Congress the power to abolish the slave trade after 1808 (if a majority in favor of so doing existed) and to tax the slave trade before that date-in part because the representatives of the Northern states demanded that their Southern counterparts contribute to the anticipated cost of suppressing any future slave revolt that threatened civil peace throughout the country (Collier and Collier 1986, Chapter 16; Dougherty and Heckelman 2008; Drinker Bowen 1966, Chapter 16; Freehling 1972).

Many of the Convention delegates acknowledged the immorality of slavery and the slave trade, but nevertheless accepted its continuation because they believed that the economic prosperity of the South depended on it (Drinker Bowen 1966, pp. 200-204). Indeed, that was the position taken by the most celebrated Founders who were themselves slaveowners. In Federalist 42, Madison (1788b, pp. 209-210) condemned slavery as a form of "barbarism" that was "unnatural". His moral repugnance "led him to act the part of humane master", but his family's privileged lifestyle, "rested on their ownership of black slaves" and "in the final judgement, he was no better prepared to live without slaves than the other members of the great planter class to which his family belonged" (Rakove 2007, p. 146). Jefferson likewise combined his public commitment to equality with, "his private life as a slaveowner whose expensive pursuit of his own happiness ... made it impossible for him to free any of his human chattel", other than those "whom were almost certainly his own offspring" (Rakove 2007, pp. 219-20).

As noted above, the Founders did not consider Africans to be equal to white Europeans. Jefferson came to support a plan for gradual emancipation of slaves, but he believed that freedmen ultimately should return to Africa, rather than become equal citizens of the new republic; accordingly, he supported the colonialization movement's plan to resettle freed slaves in Sierra Leone, Liberia, or both (Magnis 1999: pp. 502-503). However morally troubling the Founders found slavery, their views nevertheless reflected an age in which most white people thought black people to be inferior (Collier and Collier 1986, p. 141; Freehling 1972; Magnis 1999; Rakove 2007, p. 213). 
The problem of slavery in the American Founding speaks to the place of the status quo in constitutional political economy. The requirement of unanimity would seem to mean that any beneficiary of present arrangements, however abhorrent those arrangements may be, is able to veto change, so that, "The abolition of slavery is blocked by the slave owners, the redistribution of income [is blocked] by the rich", and, "If one group achieves a larger than average share of the community's income or wealth via luck, skill, or cunning ... this distribution cannot be upset by collective action of the community" (Mueller 2003, pp. 143-144).

Buchanan's unanimity principle would seem to mean that the consent of slaveowners is required before slavery can be abolished. In the absence of natural rights, slaves (like everyone else) do not possess rights until others have agreed to assign and respect them. In a constitutional agreement modelled as a series of bilateral exchanges, recognition of the rights of slaves by their masters would therefore seem to be required for manumission. The fact that Buchanan's model of constitutional agreement does not automatically rule out slavery undoubtedly is challenging, even troubling, but it is important to understand that Buchanan believed that non-consensual politics-politics in which an individual's rights may be altered without their consent-left everyone open to exploitation and even (what may amount to) enslavement (Brennan and Buchanan 1980, p. 221; Buchanan 1975a, Chapter 9, 1996; Meadowcroft 2011, Chapter 2, 2014).

The unanimity principle undoubtedly gives a privileged position to the status quo, whatever that status quo may be, but not, as Buchanan (1975b, p. 124) explained, because the status quo is deemed desirable, but because it is the inevitable starting point of change: "In a very real sense, the starting point is always the status quo, and proposals for improvement must be informed by this existential reality". The consensual politics that follows from Buchanan's constitutional political economy must begin from a starting point that is the legacy of non-consensual politics; a line must be drawn under the past from which all changes must be unanimous if a new era of consensual politics is to begin (Meadowcroft 2014). The imposition of a new constitutional order on one section of society by another simply would continue politics as usual wherein one group imposes its will on others. Buchanan (1975a, p. 213) did not believe that a long-term improvement in human affairs could result from the continuation of non-consensual politics: "Little, if any, improvement in the lot of modern man is promised by imposition of new rules by some men on other men".

The fact that slavery was not abolished in the American Founding would seem to challenge Buchanan's theoretical claim that both the strong and the weak will agree to respect one another's rights and enter constitutional agreement in order to realize the mutual gains from mutual disarmament. In eighteenth century America, the wealth that slavery and the slave trade created for some outweighed the expected benefits from the cessation of predation (i.e., the outlawing of slavery and the slave trade). Indeed, if we judge that in the long-run a free economy will become more prosperous than a slave economy, then antebellum slavery may be an example of a transitional gains trap (Tullock 1975) wherein a small number of individuals likely to incur short-term losses mobilize to prevent welfare-enhancing reform and consequently trap the economy in a relatively impoverished state. 
The fact that the hundreds of thousands of slaves who made up close to one-fifth of the American population in 1787 were not given the opportunity to participate in the constitutional agreement also is significant. ${ }^{1}$ Those Americans effectively were unrepresented at the Constitutional Convention. From the perspective of Buchanan's constitutional political economy, without the consent of African-Americans, no constitutional agreement was possible: America effectively remained in the state of nature as one group continued to impose its will on another.

Buchanan did not explicitly pursue that line of reasoning in his work, not least because he rarely explicitly addressed empirical or historical cases, but in The Limits of Liberty he identified, "wholly admirable precepts for achieving racial justice", as one of the forces wrenching apart social order in America and necessitating a new, genuinely unanimous constitutional agreement (Buchanan 1975a, p. 218). In seeking to identify the possible intellectual foundations for such a restoration of America's constitutional order, Buchanan (1975a, Chapter 9) turned to the American Founders. Their creation undoubtedly was imperfect, but their constitutional mentality envisaged a society founded on exchange and contract among moral equals that Buchanan believed represented the only way to create a just social order. In 1788, the Founders arrived at a compromise that facilitated agreement amongst themselves, which Buchanan understood to be an essential prerequisite for the achievement of a constitutional order, but as men of their time they did not go far enough in extending their constitutional wisdom to all Americans.

\section{Conclusion}

In May 1992, Buchanan gave the commencement address at Lycoming College in Williamsport, Pennsylvania. In a speech entitled, "We have lost our constitutional way", Buchanan told the graduating students that the "good society" was attainable in the here and now" if America could restore the vision of its Founders and return the government to the control of the governed. He closed his address by saying "Two centuries ago, James Madison showed us the way. We only need to translate his vision into the realities of our time" (Buchanan 1992b).

Buchanan and the Founders shared a vision of a society of moral equals founded on a nexus of contract and exchange-principles that extended to both economic and political life. The "realities of our time" was the status quo that must be the starting point of any genuinely consensual politics. Buchanan was conscious that realizing the Madisonian ideal from the status quo of contemporary America would not be easy, but he believed that a continuation of conflictual politics offered little hope for the long-term betterment of either the victors or the losers of non-consensual politics.

The abstract, formal character of Buchanan's principal works has left the practical implications of his scholarship open to interpretation. Recently, it has been understood disingenuously by writers pursuing a partisan, activist agenda who have sought to contrast Buchanan's vision with that of the American Founders. The present article has set out the commonality of vision shared by Buchanan and the Founders. Buchanan's constitutional political economy does not lead to the conclusion that the Founders went too far in creating democratic institutions; on the contrary, it leads to the conclusion that they did not go

\footnotetext{
1 The first US census undertaken in 1790 reported 694,280 slaves in a total population of 3,893,635 (see the documents available here: https://www.census.gov/library/publications/1793/dec/number-of-perso ns.html).
} 
far enough in pursuing and realizing their constitutional vision of a society of equals. If American democracy is to be restored, Buchanan's work counsels that future politics must be founded on the unanimous consent of the governed-rich and poor, white and black.

Acknowledgements An earlier version of this article was presented at the Dr. James M. Buchanan Centennial Birthday Academic Celebration, 2-5 October 2019, at Middle Tennessee State University, Murfreesboro, TN. I would like to thank Daniel J. Smith for organizing the conference, and for his comments and editorial input, and my discussant, Dean John R. Vile, for his helpful and thoughtful comments. I would also like to thank Elizabeth E. Beckman and Brittney Falter at the George Mason University Library for their assistance at the Buchanan archives. Finally, I acknowledge the generous support of the Centre for the Study of Governance and Society at King's College London.

Open Access This article is licensed under a Creative Commons Attribution 4.0 International License, which permits use, sharing, adaptation, distribution and reproduction in any medium or format, as long as you give appropriate credit to the original author(s) and the source, provide a link to the Creative Commons licence, and indicate if changes were made. The images or other third party material in this article are included in the article's Creative Commons licence, unless indicated otherwise in a credit line to the material. If material is not included in the article's Creative Commons licence and your intended use is not permitted by statutory regulation or exceeds the permitted use, you will need to obtain permission directly from the copyright holder. To view a copy of this licence, visit http://creativecommons.org/licenses/by/4.0/.

\section{References}

Bailyn, B. (1967). The ideological origins of the American revolution. Cambridge, MA: Belknap Press.

Biebricher, T. (2018). The political theory of neoliberalism. Stanford: Stanford University Press.

Boettke, P. J., \& Leeson, P. T. (2004). Liberalism, socialism, and robust political economy. Journal of Markets and Morality, 7(1), 99-111.

Brennan, G., \& Buchanan, J. M. (1980/2000). The power to tax: The collected works of James M. Buchanan (Vol. 9). Indianapolis: Liberty Fund.

Brennan, G., \& Buchanan, J. M. (1985/2000). The reason of rules: The collected works of James M. Buchanan (Vol. 10). Indianapolis: Liberty Fund.

Brown, W. (2019). In the ruins of neoliberalism. New York: University of Colombia Press.

Buchanan, J. M. (1968/1999). The demand and supply of public goods: The collected works of James M. Buchanan (Vol. 5). Indianapolis: Liberty Fund.

Buchanan, J. M. (1971). Equality as fact and norm. Ethics, 81, 228-240.

Buchanan, J. M. (1972/2005) Before public choice. In E. Stringham (Ed.), Anarchy, state, and public choice (pp. 77-87). Cheltenham: Edward Elgar.

Buchanan, J. M. (1975a/2000). The limits of liberty: The collected works of James M. Buchanan (Vol. 7). Indianapolis: Liberty Fund.

Buchanan, J. M. (1975b). Utopia, the minimal state and entitlement. Public Choice, 23, 121-126.

Buchanan, J. M. (1977a/2001). Law and the invisible hand. In The collected works of James M. Buchanan. Moral science and moral order (Vol. 17). Indianapolis: Liberty Fund.

Buchanan, J. M. (1977b). Freedom in constitutional contract. College Station: Texas A\&M Press.

Buchanan, J. M. (1979a/1999). Natural and Artifactual Man. In The collected works of James M. Buchanan. The logical foundations of constitutional liberty (Vol. 1). Indianapolis: Liberty Fund.

Buchanan, J. M. (1979b/1999). Politics without romance. In The collected works of James M. Buchanan. The logical foundations of constitutional liberty (Vol. 1). Indianapolis: Liberty Fund.

Buchanan, J. M. (1986a/1999). Better than plowing. In The collected works of James M. Buchanan. The logical foundations of constitutional liberty (Vol. 1). Indianapolis: Liberty Fund.

Buchanan, J. M. (1986b/2001). Contractarianism and democracy. In The collected works of James M. Buchanan. Choice, contract, and constitutions (Vol. 16). Indianapolis: Liberty Fund.

Buchanan, J. M. (1989a/1999). The ethics of constitutional order. In The collected works of James M. Buchanan. The logical foundations of constitutional liberty (Vol. 1). Indianapolis: Liberty Fund.

Buchanan, J. M. (1989b). Rational choice models in the social sciences. In Explorations in constitutional economics. College Station, TX: Texas A\&M University Press.

Buchanan, J. M. (1992a/2001). Virginia political economy: some personal reflections. In The collected works of James M. Buchanan. Ideas, persons, and events (Vol. 19). Indianapolis: Liberty Fund.

Buchanan, J. M. (1992b). We have lost our constitutional way. Commencement address, Lycoming College, 3 May 1992 [manuscript], James M. Buchanan Archives, George Mason University. 
Buchanan, J. M. (1996/2001). Distributional politics and constitutional design. In The collected works of James M. Buchanan. Choice, contract, and constitutions (Vol. 16). Indianapolis: Liberty Fund.

Buchanan, J. M. (1997/2001). Democracy within constitutional limits. In The collected works of James M. Buchanan. Choice, contract, and constitutions (Vol. 16). Indianapolis: Liberty Fund.

Buchanan, J. M. (2003). The constitutional way of thinking. Supreme Court Economic Review, 10, $143-156$.

Buchanan, J. M. (2007). Economics from the outside in. College Station: Texas A\&M University Press.

Buchanan, J. M. (2008). Same players, different game: How better rules make better politics. Constitutional Political Economy, 19, 171-179.

Buchanan, J. M., \& Tullock, G. (1962/1999). The calculus of consent: The collected works of James M. Buchanan (Vol. 3). Indianapolis: Liberty Fund.

Buchanan, J. M., \& Vanberg, V. (1989). A theory of leadership and deference in constitutional construction. Public Choice, 61, 15-27.

Collier, C., \& Collier, J. L. (1986). Decision in Philadelphia: The Constitutional Convention of 1787. New York: Random House.

Dougherty, K. L., \& Heckelman, J. C. (2008). Voting on slavery at the Constitutional Convention. Public Choice, 136, 293-313.

Douglass, F. (1852/2016). What to a slave is the fourth of July? In J. Stauffer \& H. L. Gates (Eds.), The Portable Frederick Douglass. New York: Penguin.

Drinker Bowen, C. (1966). Miracle at Philadelphia: The story of the Constitutional Convention May to September 1787. New York: Little, Brown.

Epstein, R. (2014). The classical liberal constitution. Cambridge, MA.: Harvard University Press.

Freehling, W. W. (1972). The Founding Fathers and slavery. The American Historical Review, 77(1), 81-93.

Hardin, R. (1988). Constitutional political economy-Agreement on rules. British Journal of Political Science, 18(4), 513-530.

Kelman, M. (1988). On democracy-bashing: A skeptical look at the theoretical and "empirical" practice of the public choice movement. Virginia Law Review, 74(2), 199-273.

Levy, D. M. (2002). Robust institutions. The Review of Austrian Economics, 15, 131-142.

Levy, D. M., \& Peart, S. J. (2018). James Buchanan and the return to an economics of natural equals. In R. E. Wagner (Ed.), James M. Buchanan, remaking economics: Eminent post-war economists (pp. 693-712). Palgrave: Basingstoke.

Locke, J. (1689/1993). Two treatises of government. Cambridge: Cambridge University Press.

MacLean, N. (2017). Democracy in chains: The deep history of the radical right's stealth plan for America. New York: Viking.

Madison, J. (1788a/2008). Federalist 42. In A. Hamilton, J. Madison \& J. Jay (Eds.), The federalist papers. Oxford: Oxford University Press.

Madison, J. (1788b/2008). Federalist 51. In A. Hamilton, J. Madison \& J. Jay (Eds.), The federalist papers. Oxford: Oxford University Press.

Magnis, N. E. (1999). Thomas Jefferson and slavery: An analysis of his racist thinking as revealed by his writings and political behavior. Journal of Black Studies, 29(4), 491-509.

Marciano, A. (2009). Buchanan's constitutional political economy: Exchange vs choice in economics and in politics. Constitutional Political Economy, 20, 42-56.

Meadowcroft, J. (2011). James M. Buchanan. New York: Continuum.

Meadowcroft, J. (2014). Exchange, unanimity and consent: A defence of the public choice account of power. Public Choice, 158, 85-100.

Mills, C. W. (1997). The racial contract. Ithaca: Cornell University Press.

Montesquieu, C. L. (1749/1961). Spirit of the Laws, Paris: Garnier.

Mueller, D. C. (2003). Public choice III. Cambridge: Cambridge University Press.

Mueller, D. C. (2013). The origins of the state. In M. Reksulak, L. Razzolini, \& W. F. Shughart (Eds.), The Elgar companion to public choice (2nd ed., pp. 57-71). Cheltentham: Edward Elgar.

Ostrom, V. (2012). Buchanan's opening to constitutional choice and meta-levels of analysis. Public Choice, 152, 427-431.

Pateman, C., \& Mills, C. W. (2007). Contract and domination. Cambridge: Polity.

Pennington, M. (2011). Robust political economy: Classical liberalism and the future of public policy. Chelthenham: Edward Elgar.

Petracca, M. P. (1991). The rational choice approach to politics: A challenge to democratic theory. The Review of Politics, 53(2), 289-319.

Pole, J. R. (1978). The pursuit of equality in American history. Berkeley: University of California Press.

Rakove, J. N. (2007). James Madison and the creation of the American Republic. New York: Pearson.

Roback, J. (1986). The political economy of segregation: The case of segregated streetcars. The Journal of Economic History, 46(4), 893-917. 
Rothstein, R. (2017). The color of law: A forgotten history of how our government segregated America. New York: Liveright.

Rousseau, J. J. (1671/1923). The social contract. London: J M Dent.

Smith, A. (1776/1981). In R. H. Campbell \& A. S. Skinner (Eds.), An inquiry into the nature and causes of the wealth of nations (Vol 1). Indianapolis: Liberty Fund.

Tullock, G. (1975). The transitional gains trap. The Bell Journal of Economics, 6(2), 671-678.

Udehn, L. (1996). The limits of public choice: A sociological critique of the economic theory of politics. London: Routledge.

Vanberg, V. J. (2004). The status quo in contractarian-constitutionalist perspective. Constitutional Political Economy, 15, 153-170.

Wood, G. S. (1992). The radicalism of the American Revolution. New York: Vintage Books.

Publisher's Note Springer Nature remains neutral with regard to jurisdictional claims in published maps and institutional affiliations. 